\title{
杭水制内外の流れと魚の挙動 \\ HYDRAULIC FUNCTIONS OF THE PILE DIKE AND ITS IMPACT ON FISH BEHAVIOR IN THE VICINITY
}

\author{
高水克哉 ${ }^{1} \cdot$ 栗原朋之 $^{2} \cdot$ 青木宗之 ${ }^{3} \cdot$ 内山文哉 ${ }^{4} \cdot$ 福井吉孝 $^{5}$ \\ Katsuya TAKAMIZU, Tomoyuki KURIHARA, Muneyuki AOKI, Fumiya UCHIYAMA and Yoshitaka FUKUI \\ ${ }^{1}$ 正会員 工修 株式会社 東京建設コンサルタント (†170-0004 東京都豊島区北大塚1丁目15番6号) \\ 2学生員 東洋大学大学院 工学研究科環境デザイン専攻 († 350-8585 埼玉県川越市鯨井2100) \\ 3学生員 工修 東洋大学大学院 工学研究科環境デザイン専攻 (†350-8585 埼玉県川越市鯨井2100) \\ 非会員 東洋大学 工学部環境建設学科 († 350-8585 埼玉県川越市鯨井2100) \\ 5正会員 工博 東洋大学教授 工学部環境建設学科 ( 350-8585 埼玉県川越市鯨井2100)
}

\begin{abstract}
This research consists of three parts. First is the study about the flow influenced by the pile dike in the river. Second is an examination of whether regions in pile dikes are suitable as a habitat for fish. Third is a numerical analysis concerning the relationship between the flow and the behavior of fish.

To complete the first part, velocity of flow and water depth in an open channel is measured. In the second part, fresh water fish (Tribolodon hakonensis) are released into the flow and their behavior is observed by video camera. Finally, the two-dimensional shallow water equation is used to examine the profile of the flow. The random walk method is adopted to examine the behavior of fish in the flow.
\end{abstract}

The flow and the behavior of fish in the channel become clean through our experiment and numerical analysis.

Key Words : pile dike, fish habitat, numerical analysis, random walk, Tribolodon hakonensis

1.はじめに

河川法の改正以来 , 自然環境の保全 , 再生や良好な景 観の構築といったような, 魚類や小動物などの生息にや さしい河川環境の整備が活発になっている.一方, 伐採 等によって生じた木材をいかに有効利用するかも重要な ことである . 兴の一つの方法として , 間伐材 $t^{1)}$ 用いた 杭水制か学代られる. 水制は, 古くから伝わる伝統的工 法であり，流速低減や水刎，流路固定，導流といったよ うな機能を持っている2) . 木を用いることは河川景観に 対して良好であり，同時に河川中に生息する樣々な生物， 主に魚類の生息に有効であるのではないかと考えられる. 乥こで本研究では，特に河川中流部を想定し，杭水制の 持つ流速低減機能, 水刎機能を種々の杭の配置て検証す ること. 光して, 杭水制群か漁の生息に対して有効であ るということを確認するために実験と数值解析を行った . 数值解析では杭の存在と魚の挙動の因果関係を明らかに する方法としてランダムウォークモデルを提唱した .
2 . 間伐材を用いた杭水制実施例

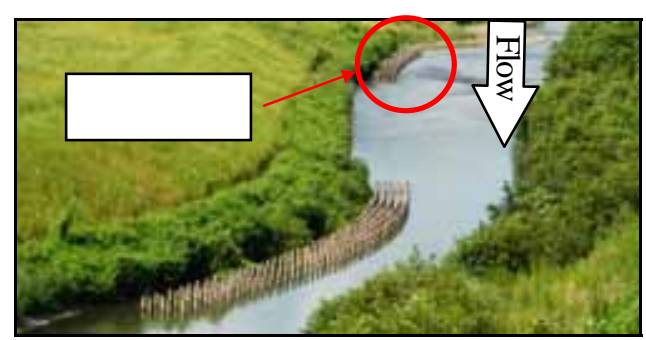

(a) 杭水制観測箇所 ( $\bigcirc$ 印)

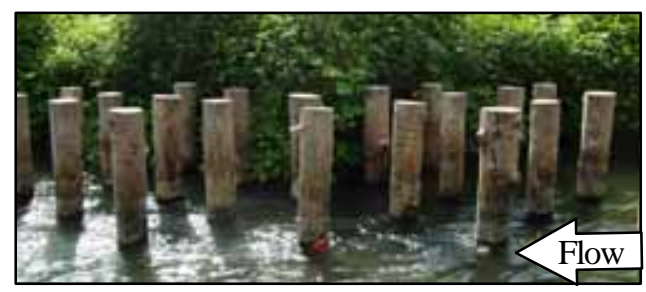

(b) 杭水制拡大図

図-1 砂鉄川 (岩手県, 北上川水系) 


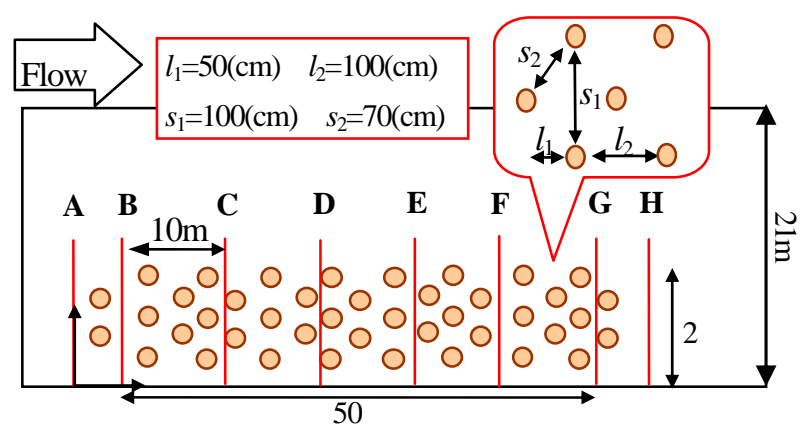

图 2 杭水制の配列(砂鉄川)

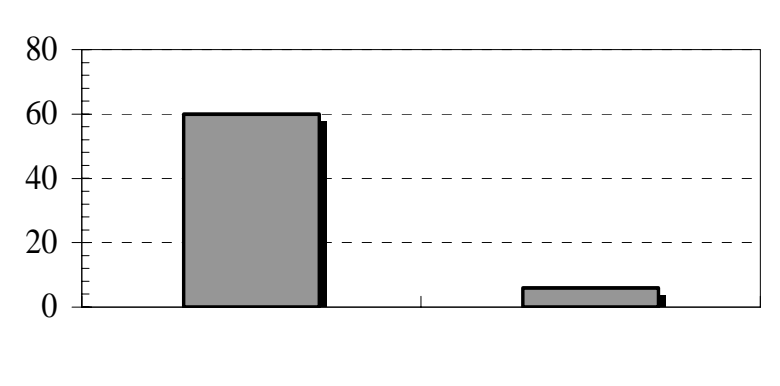

図 3 魚の生息数( 砂鉄川) $)^{3)}$

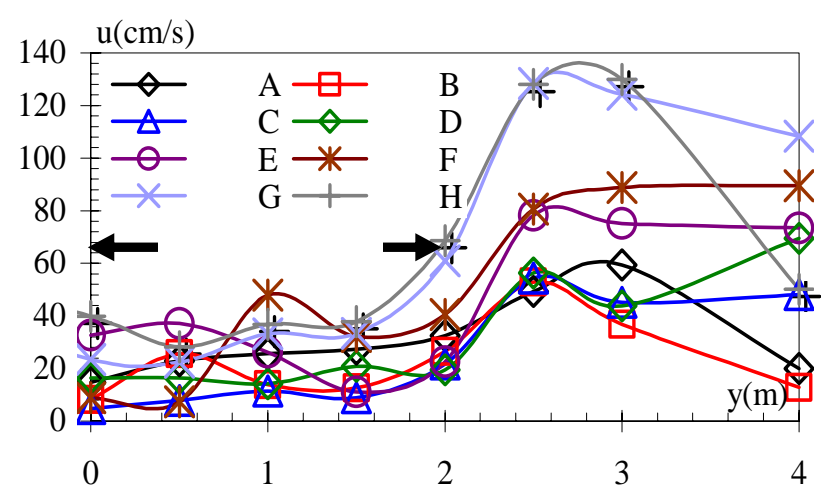

图 4 各断面における流速 (水面下 $20 \mathrm{~cm}$ )

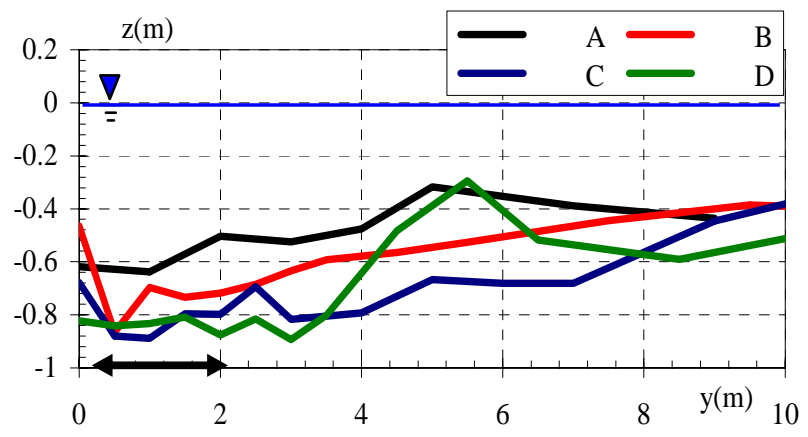

图 5 横断方向河床形状 (杭水制設置箇所)

北上川の左支川の砂鉄川の北上川との合流前約 1.0(km)門崎地先に, 直径 15(cm)の間伐材(松)を千鳥状に 並べた杭水制か平成 17 年に設置されて現在に至ってい る (図-1,2). 岩手河川国道事務所一関出張所の調査によ ると，杭水制が，設置された区間とされなかった区間の 比較から魚の生息場として適していることか判る ${ }^{3}$ ) (図 -3）なお，魚種はウグイ,アユ,アブラハヤが多かった . また, 福井らの現地調査の結果, 杭水制が流速を低減さ せる機能を発揮していることも判った (図-4) .

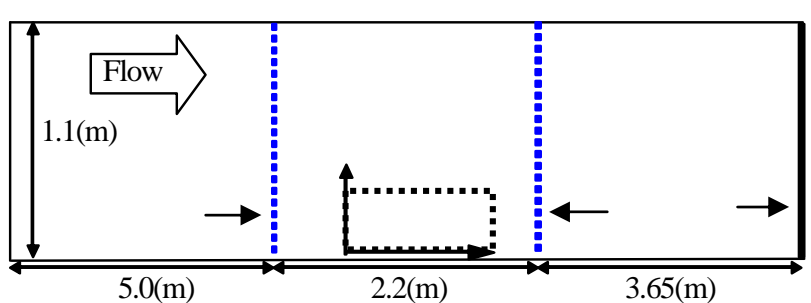

(a) 水路平面図

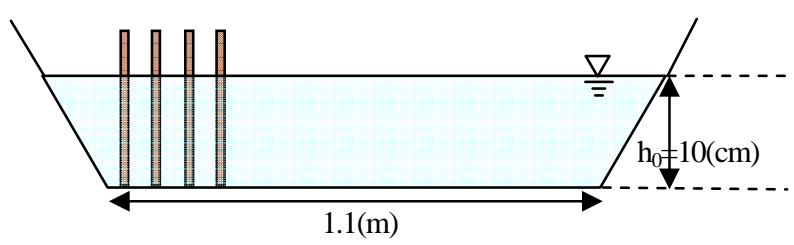

(b) 水路断面図

图-6 実験水路図

表-1 実験ケース一覧

\begin{tabular}{|c|c|c|c|c|c|}
\hline & $\begin{array}{l}\text { 円柱 } \\
\text { 本数 } \\
\text { 本) }\end{array}$ & \begin{tabular}{|c} 
横断方向 \\
設置間隔 \\
$s(\mathrm{~cm})$
\end{tabular} & $\begin{array}{c}\text { 縦断方向 } \\
\text { 設置間隔 } \\
l(\mathrm{~cm})\end{array}$ & $\begin{array}{c}\text { 密生度 } \\
\lambda\end{array}$ & $\begin{array}{c}\text { 透過係数 } \\
K \\
(\mathrm{~m} / \mathrm{s})\end{array}$ \\
\hline Run 1 & $\underline{0}$ & - & - & - & - \\
\hline Run 2 & 275 & 2 & 4 & 17.188 & 2.068 \\
\hline Run 3 & 150 & 4 & 4 & 4.688 & 2.800 \\
\hline Run 4 & 143 & 2 & 10 & 3.575 & 2.868 \\
\hline Run 5 & 78 & 4 & 10 & 0.975 & 3.883 \\
\hline Run 6 & 77 & 2 & 20 & 0.963 & 3.908 \\
\hline Run 7 & 42 & 4 & 20 & 0.263 & 5.292 \\
\hline Run 8 & 44 & 2 & 40 & 0.275 & 5.170 \\
\hline Run 9 & 24 & 4 & 40 & 0.075 & 7.000 \\
\hline
\end{tabular}

しかし光の一方, 水制内先端近傍に主流部か形成され， 流下につれて洗掘力生じていることも判った(図-5)．な お，杭水制力設置されている区間の川幅は約 21(m)，勾

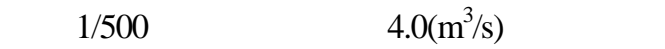

\section{3 . 模型実験}

実験に使用した水路を図-6に示す 水路は 幅1.1(m)， 長さ $10.85(\mathrm{~m})$ ，水路の側壁は $45^{\circ}$ の台形断面開水路であ る. 測定領域は $1.1 \times 2.2(\mathrm{~m})$, 流量 $Q=35.0(1 / \mathrm{s})$ とした .ま た，実験時の平均水深を魚の遊泳に必要な $10(\mathrm{~cm})$ とした . 表-1に実験ケースの一覧を示す.擬似杭水制として用 いた円柱は, 高さ $15(\mathrm{~cm})$, 直径 $d=0.5(\mathrm{~cm})$ の木製円柱で あり, 水路右側岸部に配置した . 設置間隔は横断方向 $s=2.0,4.0(\mathrm{~cm})$, 乥して縦断方向 $l=4.0,10.0,20.0,40.0,(\mathrm{~cm})$ で 6 列 12 列である. 実際の河川の杭水制は, 直径 $d=12 \sim 15(\mathrm{~cm}), s, l$ は 0.5(m) 1.0(m)が多く, 本実験て採用 した $d, s, l$ は, 水理模型実験に対して推奨されている縮 尺模型 $1 / 10 \sim 1 / 30^{4}$ に殆んどか㳔応している．一方魚の動 きを詳細に検討するために実魚を使っているので、魚の 


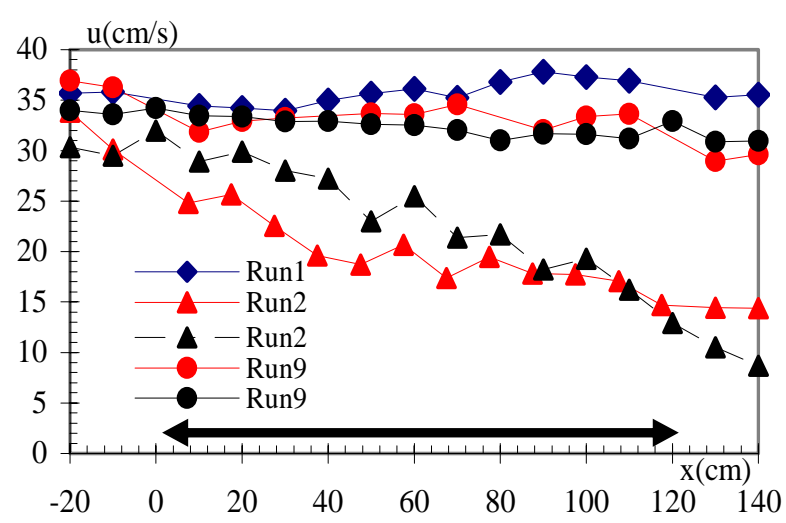

図- 7 円柱群内部の流速変化 $(y=15 \mathrm{~cm})$

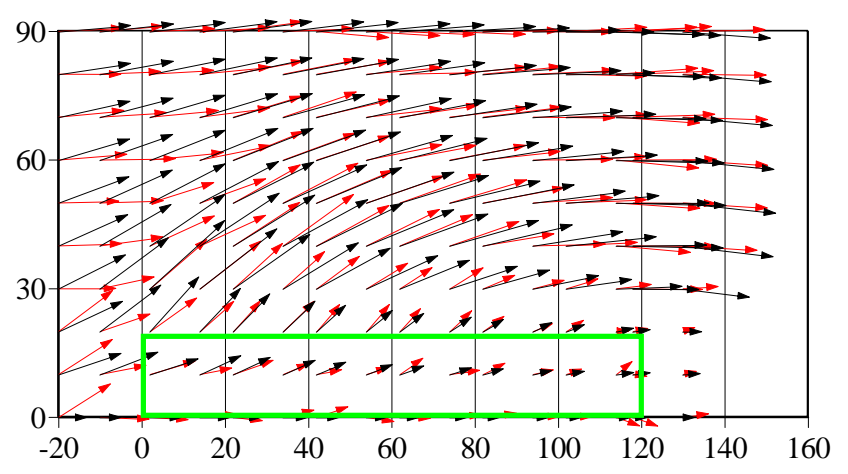

(a) Run2

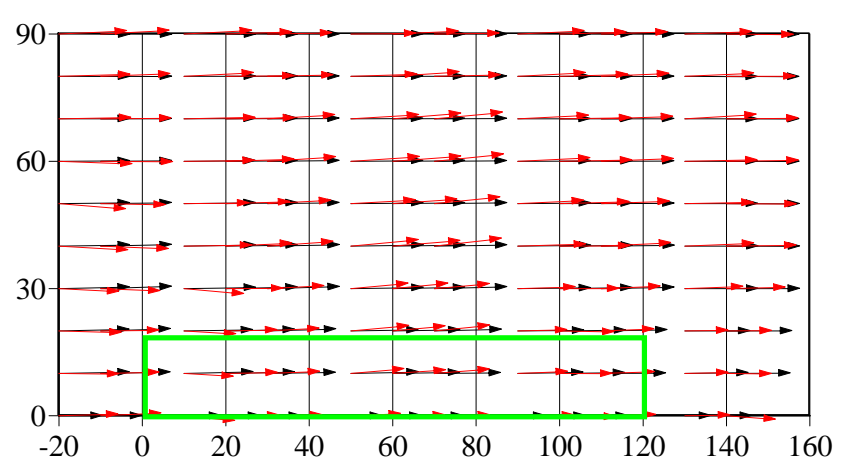

(b) Run9

$20 \mathrm{~cm} / \mathrm{s} \quad$ 実測值 $\rightarrow$ 計算值 $\rightarrow$

円柱群

図 8 แベクトル (Run9)

動き易さを考慮して $l=20.0,40.0(\mathrm{~cm})$ のケースでも実験 を行った。

（1）水理実験

a) 流速低減

図-7 は円柱群内を流下するにつれての流速変化を示 している.円柱群が流れに作用し, 流速を減少させる働 きをしており，密な配列，粗な配列共に水制の役割を果 たしているといえる．

b) 水訽

図-8( a) , ( b) にy=0 90(cm)までのuvベクトルの実測値 と計算値を示す. Run2は，円柱群密度が大な大め，偏流

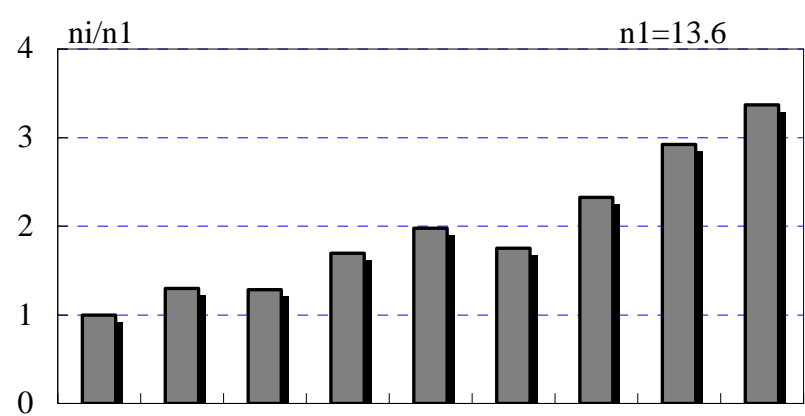

Run1 Run2 Run3 Run4 Run5 Run6 Run7 Run8 Run9

図-9 円柱群内に入ったウグイの数

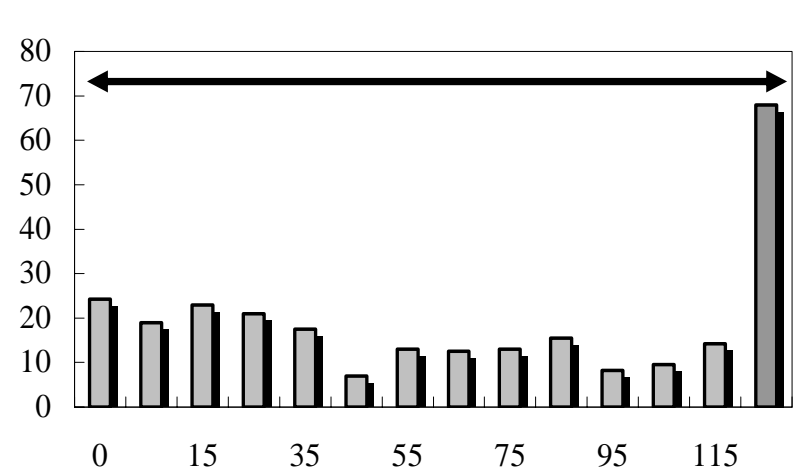

図-10 円柱群内への進入箇所と個体数 (Run9)

の規模は大きい ,一方 ,Run9は間翮が大きいので流線の 曲がりは殆んどない .

\section{（2）魚の挙動実験}

実魚を用いた模型実験は，構造物や流れの縮尺と，魚 の縮尺をどうかね合わせるかという問題を内包している . したがって何を実験魚として用いるかは，大きな問題で ある . 海洋関係では, 実際の魚が大き光のままのもの を使えないのでコイやメダカなどで行ってきているが ${ }^{5)}$ ， 本実験では日本全国の，河川の中流部の，極めて污濁の 進んだ可川を除き，ほとんどの水域に棲んているウグイ を実験魚として選んだ . 実際魚は魚種やサイズによって 水質, 照度, 水温や河岸の植生などの影響を受けて異な る動きをすることなども知られているが , 流速が大きな 支配要素であると考えて,ウグイの巡航速度 (体長の 2 4 倍の数值の流速) ${ }^{6}$ のもとて実験を行った .

実験では, 先ず円柱群より下流側に 20 匹(体長は, 6 10(cm))を放流し，流れに馴れさせてから撮影を開始し た ${ }^{7)}$. 観察領域(水路中流の $\left.1.1 \mathrm{~m} \times 2.2 \mathrm{~m}\right)^{8)}$ における魚の挙 動を，ビデオカメラで30 分間撮影した．ぞの時の照度は， 200 250(lx $)^{9)}$ とした .

a) 魚の挙動結果

円柱群に出入りしたウグイの数(ni)を図- 9 に示す . 図 は, 円柱群の無い Run1 の時に, 円柱群の領域内にいた 数(n1)を基準にして比較している.結果，砂鉄川の水制 と同樣に円柱群内に入る数が多いことが判る.今回 Run9 


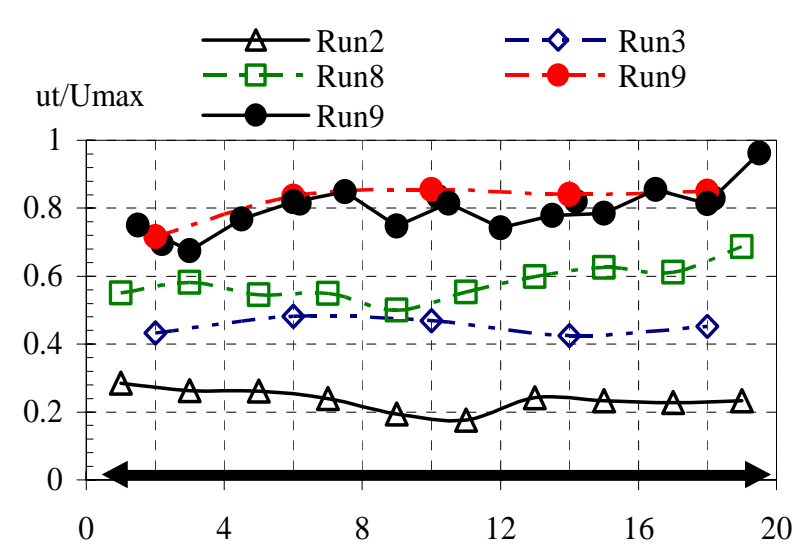

図 11 円柱群最後列の横断方向流速変化

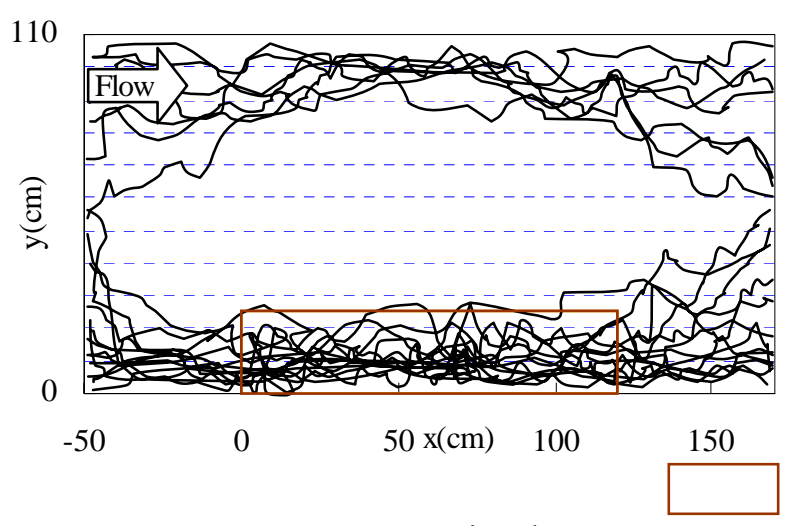

图 12 遊泳軌跡 (Run9)

で円柱群内への進入が多いことか確認できた . 次に , ウ グイがどこから円柱群に進入したかを Run9について検 討する. ウグイの円柱群内に進入した箇所と個体数を図 - 10 に示す.

円柱群の先端部から流れを横切っての進入を見ると， 進入した数は流下方向に顕著な差はみられないが, 円柱 群最後列からの進入が最も多いことか判った．図一11は， 円柱群最後列の横断方向の流速分布であり，表示されて いる值は ,円柱群最後列の円柱近傍の流速(ut)と各ケース の横断面の最大流速 $\left(\mathrm{U}_{\max }\right)$ との比で表している.他のケー スと比べ,Run9 で円柱群最後列で流速が大いことが 判る.このことから , ウグイは円柱群最後列からの速い 噴流状の流れに対して, 走流性 (流れに逆らって泳ぐ習 性)を発揮し 円柱群最後尾から進入したと考えられる . 魚の遡上軌跡図を図 12 に示す.ウグイは遡上する際， 側壁，円柱群内部を好んで移動することか確忍できた .

\section{4 . 数值解析}

水制がある場の魚の動きを数值解析により求める.

\section{（1）二次元浅水方程式による流れの解析}

水深，および流速は，二次元浅水流方程式と連続式を 用いて求める. $\leq x$ 方向の運動方程式 $>$

$$
\begin{aligned}
& \frac{\partial M}{\partial t}+\frac{\partial u M}{\partial x}+\frac{\partial v M}{\partial y} \\
& =-g h \frac{\partial H}{\partial y}-\frac{g n^{2} u \sqrt{u^{2}+v^{2}}}{h^{\frac{1}{3}}}+\frac{\partial}{\partial x}\left(\varepsilon \frac{\partial M}{\partial x}\right) \\
& +\frac{\partial}{\partial y}\left(\varepsilon \frac{\partial M}{\partial y}\right)-\frac{g}{K^{2}} M \sqrt{u^{2}+v^{2}}
\end{aligned}
$$

$\leq y$ 方向の運動方程式 $>$

$$
\begin{aligned}
& \frac{\partial N}{\partial t}+\frac{\partial u N}{\partial x}+\frac{\partial v N}{\partial y} \\
& =-g h \frac{\partial H}{\partial y}-\frac{g n^{2} v \sqrt{u^{2}+v^{2}}}{h^{\frac{1}{3}}}+\frac{\partial}{\partial x}\left(\varepsilon \frac{\partial N}{\partial x}\right) \\
& +\frac{\partial}{\partial y}\left(\varepsilon \frac{\partial N}{\partial y}\right)-\frac{g}{K^{2}} N \sqrt{u^{2}+v^{2}}
\end{aligned}
$$

$<$ <連続式 $>$

$$
\frac{\partial h}{\partial t}+\frac{\partial M}{\partial x}+\frac{\partial N}{\partial y}=0
$$

ここに, $u, v: x$ 方向,$y$ 方向の平均流速, $M, N: x$ 方向 , $y$ 方向の流量フラックス, $h:$ 水深, $H:$ 水位, $\varepsilon:$ 渦動粘 性係数である . (1), (2)式中のKは透過係数であり

$$
K=\frac{1}{\sqrt{C_{D} a_{W} / 2 g}}
$$

で表わされる.ここに $C_{D}$ : 抵抗係数であり, $a_{w}$ : 単位体 積の流体塊中にある円柱群の投影面積であり，次式によ り与えている。

$$
a_{w}=\frac{T \cdot a_{0}}{A \cdot h}
$$

ここに ,T: 円柱本数 $, a_{0}:$ 円柱 1 本あたりの総投影面積， $A$ : 円柱群設置面積である ${ }^{10)}$.

(1), (2), (3)式より求められた $u, v$ の值が，魚の挙動を表わ す式(8)を計算するときに用いられる .

計算結果は図-8に示されているが,杭間䛿狭いとき 再現性か落ちるものの概ね流れを再現できている．

\section{（2）魚の挙動解析}

魚はランダムに遊泳，移動すると考える.線形合同法 により得られる乱数列 $Z=\left(\mathrm{z}_{0} \ldots . . \mathrm{Z}_{n}\right)$ は

$$
z_{n}=a z_{n-1}+c \quad(\bmod M) \quad n \geq 1
$$

によって生成される 計算の際は 先ず初期値 $\mathrm{Z}_{0}$ を srand) 関数を用いて求め, 順次 $z_{1} \sim z_{n}$ か求まる.ここで $M$ は, 最長周期を表し， $a$ は $0<a<M, c$ は, $0 \leq c<M$ の定数と する.生成された乱数 $z_{n} に 2 \pi$ をかけることで, 流水中で の仮想魚の移動方向角度 $\theta_{n}$ を $0 \sim 2 \pi の$ 範囲で得る(式(7)) . $\theta_{n}$ は移動方向と $X$ 座標とのなす角度とする.単位時間 $\Delta t$ 後の仮想魚のいる地点は, 次式より求める. 


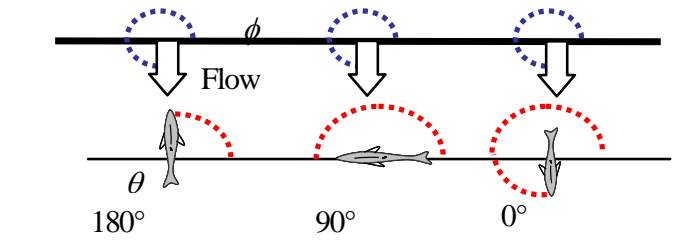

図 13 走流性を表わす係数 : $a$

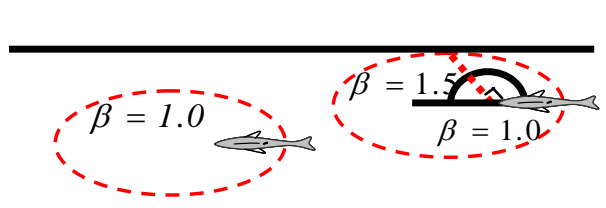

図 14 壁に対する反応を表わす係数 : $\beta$

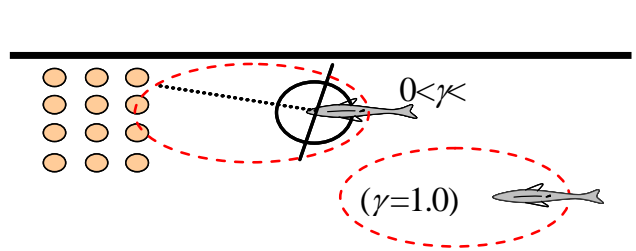

図 15 構造物に対する反応を表わす係数 : $y$

$$
\left.\begin{array}{c}
\theta_{n}=2 \pi z_{n} \\
X_{n}=\alpha \cdot \beta \cdot \gamma \cdot \Delta t\left(U_{m}-U\right) \cos \theta_{n}+X_{n-1} \\
Y_{n}=\alpha \cdot \beta \cdot \gamma \cdot \Delta t\left(U_{m}-U\right) \sin \theta_{n}+Y_{n-1}
\end{array}\right\}
$$

ここに $X_{n}, Y_{n}$ : 現在魚がいる地点の各座標 $, X_{n-1}, Y_{n-1}$ : 前 時刻の各座標， $U_{m}$ : 遊泳速度，ここでは $45(\mathrm{~cm} / \mathrm{s})$ を採用 した ${ }^{6)} \cdot U=\sqrt{u^{2}+v^{2}}$ : 光の場の流速である.走流性を 表す係数 $\alpha$, 壁に対する反応を表わす係数 $\beta$, 構造物に対 する反応を表わす係数值を(8)式へ代入することで， $X_{n}, Y_{n}$ を得ることができる .

(3) 係数 $(\alpha, \beta, \gamma)$ につて

a) 走流性を表わす係数 $\alpha$

风は走流性を表わす係数であるが，ウグイ，アユなど は走流性を持つことは広く知られており, 我々も確認し ている ${ }^{7,11)}$. 走流性の概要を图-13に示す . 流向 $\phi に$ 対し て魚の移動方向角度助 $180^{\circ}$ の時, 最も移動速度が速い とし , 走流性を表現する (式 (9)) .

$$
\left.\begin{array}{ll}
|\phi-\theta| \leqq 180 \text { のとき } \quad \alpha=\frac{|\phi-\theta|}{180} \\
|\phi-\theta|>180 \text { のとき } \quad \alpha=\frac{360-|\phi-\theta|}{180}
\end{array}\right\}
$$

b) 壁に対する反応を表わす係数 $\beta^{7}$

ßは壁に対する反応を表わす係数である.魚力壁を認 知した場合に 1.5 を入れる.これにより側壁に早く到達 し, 光の結果, 側壁選好か表現できる (図-14).$\alpha \cdot \beta に$ つては , 既に魚の挙動実験より妥当な值を得ており，

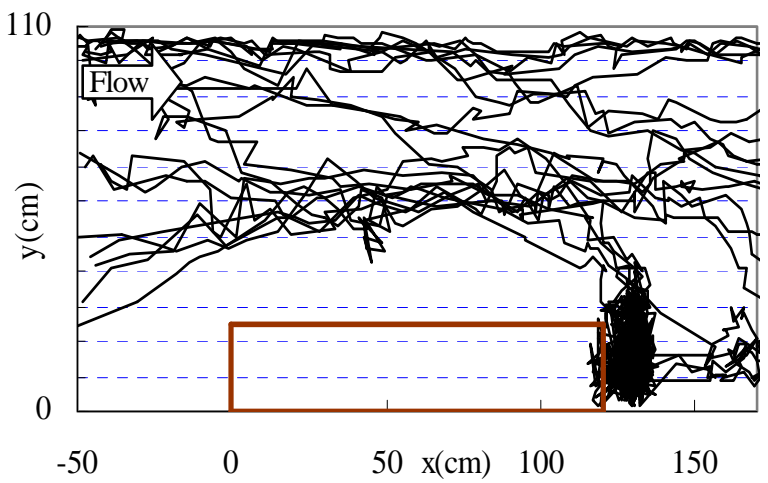

(a) $\quad y=0.1$

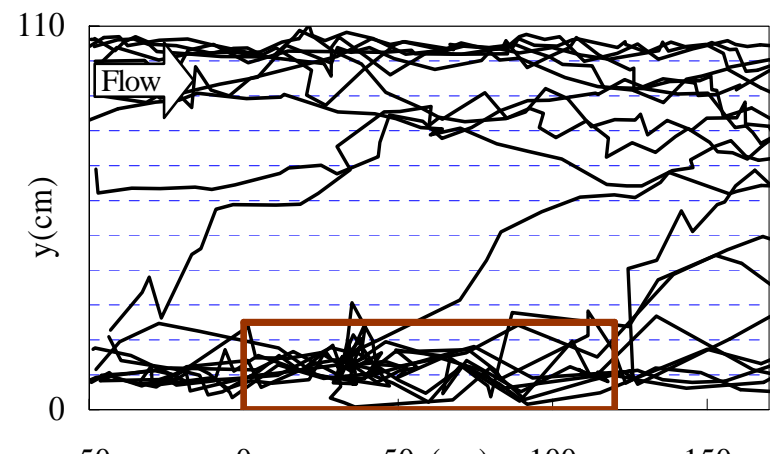

$-50$

0

$50 x(\mathrm{~cm}) \quad 100$

150

(b) $\quad y=0.5$

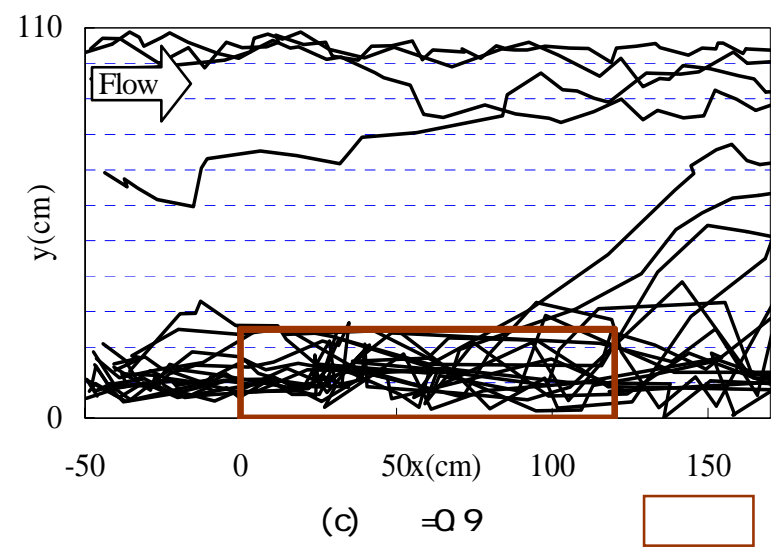

図 16 挙動軌跡图 (Run9)

兴の值を解析に取り入れている ${ }^{11)}$.

c) 構造物に対する反応を表わす係数 $\gamma$ について 水中の構造物に対する好き嫌いを表わす係数れこつい て検討を行う. 係数は 視界範囲内に円柱群がある場合， ぞれに対して $0<\gamma<1.0$ の範囲内で(8)式に与える (図-15) . 図一 16(a) , (b), (c) は, 2の值を変化させた場合の解析結果 である。

の值が 0 に近い場合, 移動距離が咸少し円柱群内入進 入しにくくなる.一方 $\gamma=0.9$ においては, 70\%位力進入 している . $/$ 值と進入する匹数の関係力泪-17 である . 実験と比較すると $\gamma=0.75$ が最適な值とみなせる .

(4) 初期值 $z_{0}$ の問題点

(6)式を用いて $z_{n}$ を順次計算していくのであるが,初期 值 $Z_{0}$ をどう定めるのかが 1 つ問題である . 図 17 に初 


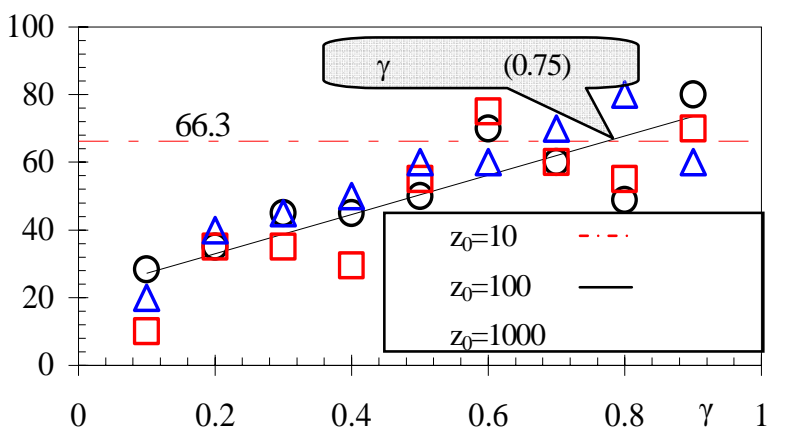

図 17 円柱群内に進入する匹数の割合

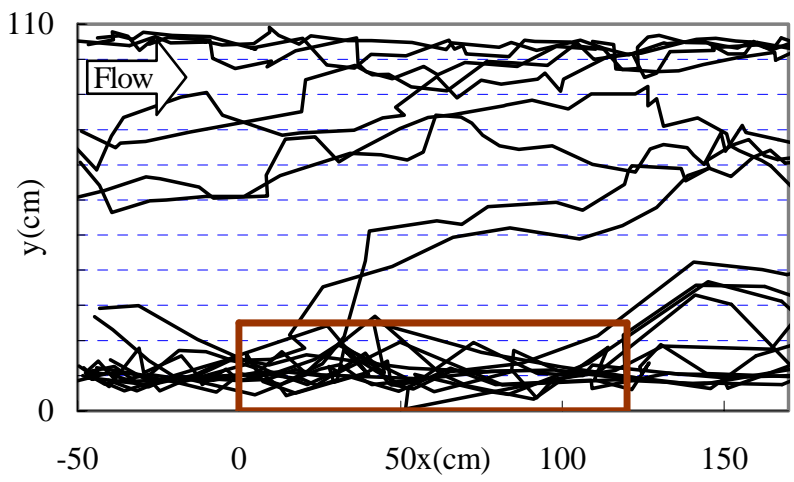

(a) $\quad y=0.75, Z_{\bar{\sigma}}=10$ (円柱群内部入 60\%進入)

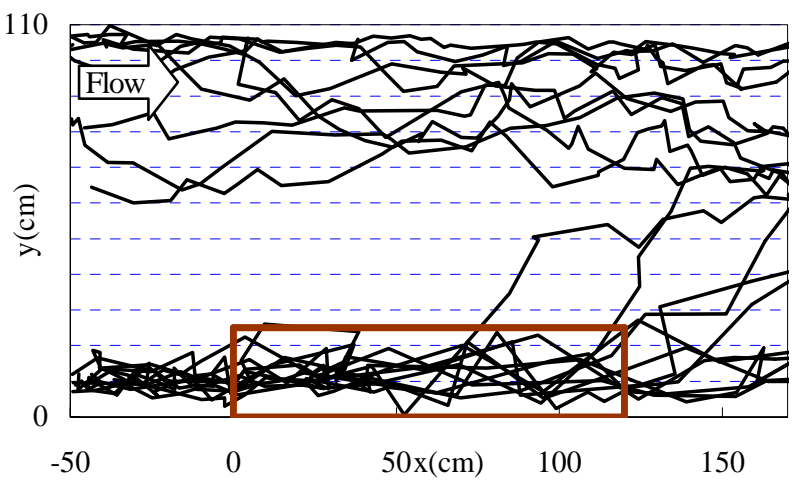

(b) $y=0.75, Z_{\bar{\sigma}}=100$ (円柱群内部入 70\%隻入) 円柱群 図-18 挙動軌跡図 (Run9)

期値 $z_{0}$ の変更結果をつの変化と共に載せている $\mathrm{z}_{0}$ の相違 により円柱群内へと入る匹数に若干の違が見られた . 光 こで，この初期值 $z_{0}$ の違いか解析結果にどのような影響 を与えるのかを見たのか泪 18(a) , (b) である . 図より， 初期値の違いによる挙動の違いは大きくないことがわか る.また，今回の計算した挙動軌跡と実験の遊泳軌跡 (図 - 12) を比較すると，円柱群に進入した匹数に着目した場 合, 初期值 $\mathrm{Z}_{0}=100$ で $70 \%$ 進入となり良好にウグイの挙動 を再現できたといえる .

\section{5 .まとめ}

1) 間伐材を用いた杭水制が，実施例から見て魚の生息 に適していることか判った .このことは，実魚を用いた
模型実験でも同樣の結果を得た .

2) 現地観測およひ模型実験から，杭水制か流速低減さ せることか判った .

3)二次元浅水流方程式て杭水制がある場の流れを概ね 再現できることか判った ただし 杭間䛿狭くなると， 計算值と実験值間での整合性か落ちてくるので，透過係 数 $K$, 抵抗係数 $C_{D}$ の更なる検討が必要である.

4)ランダムウォークモデルに魚の特性を入れることに よって 流水中の魚の挙動を的確に表わすことか出来た .

5)実魚を用いるときの流れの相似性との関係に不明な 点が多いが, 整列のみではなく千鳥状の配列での模型実 験や現地観測を行い，データを積み重ねて水制に対する 魚の対応，挙動を明らかにしていきたい. 更に，水質， 照度 , 植生などを配慮して , より精度の高いシュミレー ションモデルを構築していく予定である .

謝辞 : 砂鉄川の現地調査に当っては，国土交通省東北地 方整備局岩手河川国道事務所一関出張所の方々から御指 導，助言を頂いた ·記して謝意を表します。

\section{参考文献}

1) (財)河川環境管理財団 : 河川砂防工事における木材活用 工法ガイドブック(案) , 山海道 , pp. 89, 2004

2) 秋草 勲,吉川秀夫, 坂上義太郎, 芦田和男, 土屋昭彦: 水制に関する研究, 土木研究所報告, 第 107 の 6, pp. 2, 1960

3）国土交通省東北地方整備局: 平成 18 年度東北地方整備 局管内技術研究発表会ホームページ，

http://www.thr.mlit.go.jp/Bumon/B00097/k00360/happyoukai/ H18/2bikoku/2-18.pdf, 2006/8/15

4) 山本晃一 : 護岸・水制の計画・設計-一歩先光して一 歩手前 - , 山海堂 , pp. 238, 2003.

5）小池 篤: 漁具に対する魚群行動の研究方法, 恒星社厚 生閣 , pp. 120-121

6) 中村俊六 : 魚道のはなし , 山海堂 , pp. 169-170, 1995

7) 関谷 明, 福井吉孝, 下村 充, 打田 剛: 魚類の迷入 と艺の防止法, 土木学会論文集, No.782, pp. 81-91, 2005

8)石川雅朗 : ウグイの挙動特性に関する実験的研究，河川 技術論文集，第6 巻, pp. 101-106, 2004

9）国土交通省中国地方整備局 : 岡山河川事務所ホームペー ジ ,

http://www.okakawa-milt.go.jp/kouhou/kyougikai/kaitou2.pdf, 2006/8/18

10) (財)リバーフロント整備センター : 河川における樹木管 理の手引き , 山海堂 , pp. 107, 1999

11) 下村 充, 白川裕之, 福井吉孝, 関谷 明, : 迷入防止 法の開発 -ランダムウォークによる魚の挙動解析と光 の応用 - : 河川技術侖文集, 弟 8 巻, pp. 337-342, 2002

(2006 . 9 . 30受付) 